\title{
Influence of adaptive systems of the basic cultivation and fertilizing on the content of easy-hydrolyzable nitrogen in light grey forest soil of Polissya
}

\author{
O. Yakovenko \\ candidate of ZhNAEU
}

The purpose. To determine dynamics of the content of easy-hydrolyzable nitrogen at long-term application (25 years) of soil-protective techniques in conditions of different fertilizer systems. Methods. Field, laboratory, variation-statistical and relative analysis. Results. It is determined that the content of easyhydrolyzable nitrogen in arable layer $(0-20 \mathrm{~cm})$ of light grey forest soil in the end of the 3-rd crop rotation have made 4,02 - 11,6 mg/100 g of soil $(109,3-315,5 \mathrm{~kg} /$ hectare). That testifies to low extent of security of plants with the given nutrient. Conclusions. Agricultural techniques, which are based on minimization of cultural operations (subsurface and disk cultivation), in a combination with organic-and- mineral fertilizer system have ensured the high content of easy-hydrolyzable nitrogen $-312,8-315,5 \mathrm{~kg} / \mathrm{hectare}$.

Key words: Polissya, easy-hydrolyzable nitrogen, soil-protective cultivation, fertilizer system, light grey soil.

Problem stating. The main role in crops increase of agricultural plants belongs to Nitrogen (1, 2, and 3). It is part of protein substance and of many other natural vital important organic compounds for plants: lipids, chlorophyll, nucleoproteids, phosphatides, alkaloids, and different ferments $(4,5$, and 6$)$.

Salts of nitric acid (nitrates and salts of) and salts of ammonium are the main source of nitrogen for plants.

In natural conditions the nutrition of plants with nitrogen is done by their consumption of anion $\mathrm{NO}_{3}$ and cation $\mathrm{NH}_{4}+$, which are situated in soil solution and in the exchange uptake of soil colloid state $(4,7,8)$.

The more results of researches affirm that during mellowing without turning over the layer the differentiation of topsoil layer is strengthened with the concentration of nutriments: their concentration is increasing in the top layer $0-10 \mathrm{~cm}$ and is decreasing in the down layer $10-20 \mathrm{~cm}$ and leads to the more even distribution of these elements out of ploughing (9). Some researchers consider that this phenomenon is negative for plants nutrition, the optimal conditions for their development are formed while even distribution of nutrition elements in the layer are not less than 0-20 cm (10).

In general the question of influence of different cultivation and fertilizing systems on the index of fertile soil in different duration of their usage, in certain climate soil conditions, especially in the region of Polissya is studied insufficiently.

The main of our researches was to define the dynamic concentration of easy hydrolyzed nitrogen in the light grey forest soil during the prolonged usage ( 25 years) of soil protection agro technologies on the base of different fertilizing systems.

The researches were fulfilled in the stationary research put in 1992 on the territory of research field of ZHNAEU, Zhytomyr region, Chernihiv, V. Gorbasha village in the 8-fields corn cultivated crops on the standard for the zone of light grey forest soil.

With the scheme of research, it was expected the study of 4system technologies for soil cultivation, that is:

1. General technology on the base of ploughing on the depth of $18-20 \mathrm{~cm}$, (control, in abbreviated form P 18-20)

2. Soil protection technology based on cultivation without rotation of the layer, flat mellowing on the depth $18-20 \mathrm{~cm}$ (in abbreviated form - SF 18-20)

3. Soil protection technology based on cultivation without rotation of the layer, disk mellowing on the depth 10-12cm (in abbreviated form - SD 10-12) 
4. Soil protection depth variated technology: for winter crops- disking on the depth $10-12 \mathrm{~cm}$, for spring crops - flat mellowing on the depth $18-20 \mathrm{~cm}$ (in abbreviated form - SV).

According to these methods of cultivation, four systems of fertilizing goods were researched and they expected:

1. The variant without fertilizer (control on the base of natural fertility, fertilizers were not used since 1992)

2. sideline products $+N$ on the tone (straw $1,25 \mathrm{t} /$ hectare $+N 12,5 \mathrm{~kg} / \mathrm{ha}$ of crops area)

3. A generally accepted system of fertilizing for Polissya zone. It expected yearly applying mineral fertilizers $\mathrm{N}_{\mathrm{A}} \mathrm{P}_{\mathrm{K}}$ and 6,25 tons of humus on 1 hectare of crops area.

4. The alternative system of fertilizing $-6,25$ tons of humus + straw 1,25 tones/hectare $+\mathrm{N} 12,5 \mathrm{~kg} / \mathrm{ha}+$ green manure 5,62 tons/hectare $+\mathrm{N}_{i} \mathrm{P}_{i} \mathrm{~K}_{k}$. Oil radish was used for green manure.

The crops area is $196 \mathrm{M}^{2}(14 \times 14)$, registration area is $100 \mathrm{M}^{2}(10 \times 10)$. Repetition is three times, the placement of areas is systematic.

The researches were done in the experimental 8-fields crops with such alternation of plants: red clover (green mass), oats (grain), winter wheat, soy, oats (grain), winter rye, potatoes, and barley with seed of clover.

To provide statistic confidence as for indexes of soil fertility there were chosen mixed samples out of 384 points using the depth $1-10$ and $10-20 \mathrm{~cm}$ (11).

The concentration of easy hydrolyzed nitrogen according to the methods of Kornfild (12). Mathematics calculations and analysis of results were done via program Excel.

The results of the researches

As a result of our researches it's specified that concentration of easy hydrolyzed nitrogen in the topsoil layer $(0-20 \mathrm{~cm})$ of light grey forest soil depending on the fertilizing systems and methods of the general cultivation was between $40,2-116,0 \mathrm{mg} / \mathrm{kg}$ of soil $(1093,4-3155,2 \mathrm{~kg} / \mathrm{hectare}$, table.1).It shows the low level of plant provision by this nutrition element.

The concentration of easy hydrolyzed nitrogen mostly depended on the methods of the main cultivation in the variant without usage of fertilizers. In particular using the permanent ploughing its balance decreased to $737,0 \mathrm{~kg} / \mathrm{ha}$, but using beardless method of cultivation $-590,0-666,0 \mathrm{~kg} / \mathrm{hectare}$.

Because of systematic usage of straw $1,25 \mathrm{t} /$ hectare $+\mathrm{N}_{12,5} \mathrm{~kg} / \mathrm{hectare}$ for crops area (the variant of fertilizing 2 ) we observe the stable positive balance of the concentration of easy hydrolyzed nitrogen. Using this fertilizing system the concentration of nitrogen increased in comparison with results on the base of ploughing to $15,5 \mathrm{mg} / \mathrm{kg}$ of soil $(422,0 \mathrm{~kg} / \mathrm{ha})$, while using flat mellowing on the $15,8 \mathrm{mg} / \mathrm{kg}$ of soil $(430,0 \mathrm{~kg} / \mathrm{ha})$, disk mellowing $-17,3 \mathrm{mg} / \mathrm{kg}$ of soil $(471,0 \mathrm{~kg} / \mathrm{ha})$ and different depth cultivation $-15,6 \mathrm{mg} / \mathrm{kg}$ of soil $(424,0 \mathrm{~kg} / \mathrm{ha})$.

While using the intensive organic-mineral systems of fertilizing the concentration of easy hydrolyzed nitrogen increased, in comparison with the initial balance to $25,5 \%$ using traditional cultivation and 30,6$39,5 \%$ using soil protection beardless. Conducted perennial researches show that it's possible to decrease the doses of nitrogen fertilizers in the general system of fertilizing with the aim of its rational usage.

Table 1 Dynamics of the concentration of easy hydrolyzed nitrogen in the topsoil layer $(0-20 \mathrm{~cm})$ of light grey forest soil under three rotations of crops

\begin{tabular}{|c|c|c|c|c|c|}
\hline \multirow{3}{*}{$\begin{array}{l}\text { A method of soil } \\
\text { cultivation }\end{array}$} & \multicolumn{2}{|c|}{ Concentration of easy hydrolysed, $\mathrm{g} / \mathrm{kg}$} & \multirow{2}{*}{\multicolumn{3}{|c|}{ Changes }} \\
\hline & \multirow[b]{2}{*}{1992 year } & \multirow{2}{*}{$\begin{array}{l}\text { Average for } 2014- \\
2016 \text { years }\end{array}$} & & & \\
\hline & & & $\pm \mathrm{mg} / \mathrm{kg}$ & $\mathrm{kg} / \mathrm{ha}$ & $\begin{array}{l}\text { In } 1 \text { year } \\
\mathrm{kg} / \mathrm{ha}\end{array}$ \\
\hline \multicolumn{6}{|c|}{ Without fertilizers } \\
\hline P 18-20 & 67,0 & 40,1 & $-27,1$ & $-737,0$ & $-29,5$ \\
\hline SF $18-20$ & 67,0 & 43,5 & $-23,6$ & $-642,0$ & $-26,0$ \\
\hline SD 10-12 & 67,0 & 45,5 & $-21,7$ & $-590,0$ & $-24,0$ \\
\hline SV & 67,0 & 42,6 & $-24,5$ & $-666,0$ & $-27,0$ \\
\hline
\end{tabular}




\begin{tabular}{|c|c|c|c|c|c|}
\hline P 18-20 & 64,0 & 79,6 & 15,8 & 430,0 & 17,2 \\
\hline SF $18-20$ & 64,0 & 79,8 & 16,0 & 435,0 & 17,0 \\
\hline SD 10-12 & 64,0 & 81,2 & 17,4 & 473,0 & 19,0 \\
\hline SV & 64,0 & 79,7 & 15,8 & 430,0 & 17,2 \\
\hline \multicolumn{6}{|c|}{ Fertilizer variant $3\left(6,25 \mathrm{t} / \mathrm{ha}\right.$ humus $\left.+\mathrm{N}_{\sharp} P_{\mathrm{s}} \mathrm{K}_{\mathrm{s}}\right)$} \\
\hline P 18-20 & 70,0 & 93,9 & 24,2 & 658,0 & 26,0 \\
\hline SF $18-20$ & 70,0 & 114,8 & 45,0 & 1224 & 49,0 \\
\hline SD 10-12 & 70,0 & 115,8 & 46,0 & 1251 & 50,0 \\
\hline SV & 70,0 & 100,9 & 31,0 & 843,0 & 34,0 \\
\hline \multicolumn{6}{|c|}{$\begin{array}{l}\text { Fertilizer variant } 4(6,25 \mathrm{t} / \mathrm{ha} \text { humus }+ \text { straw } 1,25 \mathrm{t} / \mathrm{ha}+\mathrm{N} 12,5 \mathrm{~kg} / \mathrm{ha}+\text { green manure 5,62 t/ha }+ \\
\left.\qquad \mathrm{N}_{31} \mathrm{P}_{32} \mathrm{~K}_{36}\right)\end{array}$} \\
\hline P 18-20 & 67,0 & 76,3 & 9,30 & 253,0 & 10,0 \\
\hline SF $18-20$ & 67,0 & 78,9 & 12,0 & 326,0 & 13,0 \\
\hline SD 10-12 & 67,0 & 78,2 & 11,3 & 307,0 & 12,0 \\
\hline SV & 67,0 & 73,2 & 6,30 & 171,0 & 7,00 \\
\hline HIP 05 total & \multicolumn{5}{|l|}{42} \\
\hline
\end{tabular}

The concentration of $\mathrm{N}$ easy hydrolyzed on the base of alternative fertilizing system increased in comparison with output concentration to $252,0 \mathrm{~kg} / \mathrm{ha}(12,2 \%)$ using ploughing, $326,0 \mathrm{~kg} / \mathrm{ha}(15,1 \%)$ under flat cultivation, $307,0 \mathrm{~kg} / \mathrm{ha}(14,4 \%)$ under disk and $171,0(8,5 \%)$ under different depth cultivation.

\section{Conclusion}

1. Growing of agricultural plants in 8 fields crops without adding organic and mineral fertilizes and decrease of sowing area of perennial beans plants lead to decrease of the concentration of $N$ easy hydrolyzed in the topsoil layer to $24,0-27,0 \mathrm{~kg} / \mathrm{ha}$ under beardless method of soil cultivation and $2,95 \mathrm{~kg} / \mathrm{ha}$ on the base of ploughing within 1year;

2. The best accretion of easy hydrolyzed nitrogen is observed while using the intensive organic-mineral systems of fertilizing and its concentration in comparison with initial sate increased under ploughing to $658,0 \mathrm{~kg} / \mathrm{ha}$, flat mellowing $-1224,0 \mathrm{~kg} / \mathrm{ha}$, disk mellowing $-1251,0 \mathrm{~kg} / \mathrm{ha}$ a organic-mineral systems of fertilizing and different depth $-843,0 \mathrm{~kg} / \mathrm{ha}$, that is $2,6-4,9$ times more than under alternative system of fertilizing;

3. As for the connection of the level of easy hydrolyzed nitrogen accretion with the technologies of soil cultivation, you can see the advantage of soil protection flat and disk methods. Within 3 rotations the increase of nitrogen concentration under flat mellowing was $15,2-39,1 \%$, disk cultivation $14,4-39,7 \%$ and on the base of ploughing $12,2-25,7 \%$.

\section{Prospects of further searches in this direction}

The further researches will be directed on the study of the dynamics influence of long term usage of different fertilizing systems and cultivation as for the change of agrochemical and agro physical properties of soil (the concentration of humus, moving phosphorus, exchange potassium, level of $\mathrm{pH}_{0}$ )) and quantity indexes of agricultural plants.

\section{References}

1. Малієнко А.М. Вплив різних способів обробітку на фізико-хімічний стан дерново-підзолистого ґрунту та продуктивність озимої пшениці/А.М. Малієнко, Н.М. Тараріко, Г.І Личук//Землеробство.1995. -

№ $70 .-$ C. $33-39$.

2. Adewopo J.B. Top-Ranked Priority Research Ques-tions for Soil Science in the 21st Century/ J.B. Ade-wopo, Ch. Van Zomeren, R.K. Bhomia//Soil Science Society of America J. - 2014._-V. 78. - P. $337-347$. 
3. Oik D.C. Overview of the symposium proceedings, «Meaningful pools in determining soil carbon and nitrogen dynamics»/D.C. Oik, E.G. Gregorich//Soil Sci. Soc. Am. J. -2006. - V. 70. - P. 967-974.

4. Землеробствозосновамиґрунтознавстваі агро-хімії:підручник, 2-гевид. перероб. тадоп./В.П.Гудзь, А.П. Лісовал, В.О. Андрієнко, М.Ф. Рибак. - К.: Центр учб. літ-ри, 2007. - 408 с.

5. Основи землеробства: підручник/О.Ф.Смаглій, М.Ф. Рибак, Є.М. Данкевич та ін. - Житомир: Видво ДВНЗ «Державний агроекологічний університет», 2008. -514 c.

6. Bykin A.V. The effect of the fertilizer application on the texture of soil and on the density of medowcernozemsc calcareous soil in conditio of right-bank forest-steep of Ukraine/A.V. Bykin, N.P. Bordyuzha//New Advances in Research and Management of World Mollisoils: Proceedings of International Symposium on Soil Quality and Management of World Mollisoils (Harbin, China, July 13 - 16, 2010)/Eds: Xiaobing Liu, Chunyu Song, Richard M. Cruse, Ted Huffman. - Harbin: Northeast Forestry university Press, 2010.

7. Основи ведення сільського господарства та охорона земель: навч. посіб./Н.Х. Грабак, І.Н. Топіха, В.М. Давиденко, І.В. Шевель. - К.: ВД «Професіонал», 2006. - 496 с.

8. Городній М.М. Агрохімія: підручник/М. М. Город-ній. - К.: Арістей, 2008. - 934 с.

9. Гордієнко В.П. Прогресивні системи обробітку ґрунту/В.П. Гордієнко, А.М. Малієнко, Н.Х. Грабак.Сімферополь: Кримська Академія гуманітарних наук, 1998. - 279 с.

10. Зміна агроекологічних властивостей сірих опідзолених ґрунтів залежно від способів обробітку та систем удобрення в польовій сівозміні Полісся/М.С. Чер-нілевський, Н.Я. Кривич, М.Ф. Рибак та ін.//Агро-хімія і ґрунтознавство. - 1998. - Ч. 2. - С. $183-184$.

11. Мойсейченко В.Ф. Основи наукових досліджень в агрономії: підручник/В.Ф. Мойсейченко, В.О. Єщен-ко. - К.: Вища шк., 1994. - 334 с.

12. Мельничук Д.І. Якість ґрунтів та сучасні стратегії удобрення/Д.І. Мельничук, Дж. Хофман, М.М. Го-родній. - К.: Арістей, 2004. - 487 с. 